\title{
Cultivation of Applied Talents Based on the Three-in-one Platform of Industry-university-research
}

\author{
Zhijin $\mathrm{Xu}^{1, \mathrm{a}}$, Yankui Song ${ }^{2, \mathrm{~b}}$ \\ ${ }^{1}$ College of Management, Capital Normal University, Beijing, China \\ ${ }^{2}$ College English Department, Capital Normal University, Beijing, China \\ axzjccc@sina.com, bsylviasong@163.com
}

Keywords: Cultivation of applied talents, Three-in-one platform of industry-university-research, Characteristics of the times, Historical inevitability, Realistic path.

\begin{abstract}
With the economic globalization and social informatization, it has received more and more widespread attention to cultivate applied talents based on the cooperation of industry, university and research. In order to better cultivate applied talents and realize the people's all-round development, this paper explores the characteristics of the times, the historical inevitability and the selection of realistic paths of cultivating applied talents based on the three-in-one platform of industry-university-research. This paper holds that cultivating applied talents based on the three-in-one platform has the characteristics of the times of applicability, complexity and practicality. It has the historical inevitability in its development, which reflects the historical achievements of the continuous progress of science \& technology, the objective requirements of the sustainable development of economy \& society and the inherent requirements of the cultivation of modern talents and the development of higher education. It is the selection of realistic paths to cultivate applied talents based on the three-in-one platform for realizing the intersection of literal arts \& sciences, the integration of knowledge \& practice and the coordination of one specialty \& multi-capability.
\end{abstract}

\section{Introduction}

With the economic globalization and social informatization, the relationship of three-in-one is gradually constructed among the cooperation of industry, university and research ${ }^{[1]}$. It has received more and more widespread attention to cultivate applied talents based on the three-in-one platform of industry-university-research.

Cooperation has become an important feature in the development of economy, society, culture and education. However, research on the cooperation among industry, university and research often stays on the surface and does not go into the essence, let alone to probe into their three-in-one relationship ${ }^{[2]}$. In fact, cultivating applied talents based on the three-in-one platform of industry-university-research is not only the historical achievements of the continuous progress of science \& technology and the objective requirements of the sustainable development of economy \& society, but it also is the inherent requirements of the cultivation of modern talents and the development of higher education. In order to better cultivate applied talents, this paper explores initially the characteristics of the times, the historical inevitability and the selection of realistic paths of cultivating applied talents based on the three-in-one platform.

\section{Characteristics of the times}

Keys to the development of science \& technology, economy and society lie in the cultivation of talents, especially that of applied talents. Our country proposed to strengthen the cultivation of applied talents and the State Council issued the Decision on Accelerating the Development of Modern Vocational Education in 2014 for the purpose to deploy to accelerate the development of modern vocational education and to emphasize the cultivation of applied talents ${ }^{[3]}$. The decision clearly defines the guiding ideology, basic principles, objectives, tasks and policy measures for our 
country to accelerate the development of modern vocational education and cultivate applied talents in the future. It guides the transformation of a number of general undergraduate colleges into the applied technology universities and focuses on the establishment of undergraduate vocational education. It proposes to establish modern vocational education system in 2020 which adapts to the needs of the deep integration of production \& education, the connection of secondary \& higher vocational education and the mutual communication of vocational \& general education, and embodies the ideas of lifelong education with Chinese characteristics and the world level.

Generally speaking, applied talents refer to the skilled talents who can apply the mature technology and theory into the actual production and life, who are mainly engaged in front-line production of technical or professional and who skillfully master essential knowledge and basic skills of social production or social activity. The cultivation of applied talents based on the three-in-one platform of industry-university-research has distinctive characteristics of the times.

\subsection{Applicability}

The cultivation of applied talents based on the three-in-one platform has the characteristic of outstanding applicability. According to the needs of local social \& economic development and the actual requirements of front-line production, it especially emphasizes the applied foundation and mature knowledge and pays attention to service for regional trade development in aspects of the curriculum, teaching material construction and professional construction. The value orientation of its quality is fully embodied in the applicability of trade. As early as 1960s, University of Applied Sciences was founded in Germany whose purpose is to meet trade needs, to combine theory with practice, to achieve regional economic services and to carry out applied research and development through the integration of industry, university and research ${ }^{[4]}$. Obviously, applicability is the core ability and advantage of applied talents.

\subsection{Complexity}

The cultivation of applied talents based on the three-in-one platform also has the characteristic of outstanding complexity. It pays attention to the skilled mastery and flexible application of basic knowledge. It emphasizes both solid theoretical foundation and strong practical ability. Having outstanding compound ability, they are different from the theoretical talents cultivated by comprehensive research universities, and different from talents with practical skills cultivated by vocational skills colleges as well. Not only can they master all kinds of advanced skills in the management and direct operation of modern production, construction and service, but they also have the ability to transform high \& new technology into productive forces, that is the design and development ability.

In fact, applied talents cultivated based on the three-in-one platform are compound talents, which mainly includes three aspects. Firstly, applied talents have a profound professional theory based on general knowledge and a widely migrated knowledge platform. They have a strong ability of lifelong learning, adaptability of professional transformation, and a potential for further development. Secondly, they have the ability of practical application and innovation, social adaptability to solve the actual production, service, management and other aspects of knowledge \& technology. Thirdly, they have the comprehensive quality of necessary humanity, scientific spirit and that of morality \& psychology with innovative spirit, team spirit and professionalism.

\subsection{Practicality}

The cultivation of applied talents based on the three-in-one platform also has the characteristic of outstanding practicality. It emphasizes the combination with the practice of front-line production, strengthens the training of practical and operation ability, and pays more attention to practical teaching, such as experiment teaching and production practice. Therefore, there is no such high requirements generally for research talents who lay special emphasis on graduation design and dissertation.

The cultivation of applied talents, on one hand, encourages applied talents to master the theory in the course of study and practice. It emphasizes the combination of practice teaching and theory 
teaching. Students can be applied to work practice as early as possible in order to adapt to the work in the future. On the other, it advocates applied talents to actively participate in the technical research and development of the trade, to solve the specific technical problems in the production process for the trade and to combine learning at work with work in study.

In a word, the cultivation of applied talents based on the three-in-one platform of industry-university-research is a complex process. Government, universities, enterprises and research institutions must closely cooperate through various ways to achieve mutual benefit and common development, to strengthen the construction of three-in-one platform, to perfect the cultivating mechanism of applied talents with the combination of theory \& practice and to realize the people's all-round development.

\section{Inevitability of history}

The cultivation of applied talents based on the three-in-one platform of industry-university-research is the outcome of scientific \& technological progress to a certain stage. It is not only the objective requirements of economic \& social development, but it also is the inherent requirements of the growth of applied talents. Its emergence and development has its own historical inevitability.

\subsection{Historical outcome of scientific and technological progress}

The cultivation of applied talents based on the three-in-one platform came into being with the continuous progress of modern science \& technology ${ }^{[5]}$. As we know, in the whole process of science, there have been two important modes of development: continuous differentiation and continuous integration. It seems the two are the opposites of development, but in fact they are closely related. Their mutual relation and mutual penetration constitute an important part of the self movement of scientific development. Human's understanding of nature in modern times emphasizes the role of abstract analysis.

However, differentiation and integration are interdependent and inseparable. Integration is to synthesize all the parts of knowledge on the base of analysis. When the increasing differentiation of scientific knowledge recognizes the nature of different areas and ranges with the help of different subjects, the further development of science increasingly requires to summarize the scientific knowledge of each subject and to reveal the unity of nature behind its various phenomena.

In particular, with the development of modern science from the end of the $19^{\text {th }}$ century, the two modes of scientific differentiation and integration accelerated significantly. The distinctive feature of modern science is to be highly differentiated and highly integrated. The integrated development mode has been dominant during the development of the whole modern science after World War II. In the face of the stronger developing trend of science \& technology integration and the intensified intersecting of natural \& social sciences, questions have arisen of how to deal with the relationship between the special and the versatile and how to cultivate special talents, simultaneously pay attention to the education of the versatile or compound talents.

\subsection{Objective needs of social development}

The cultivation of applied talents based on the three-in-one platform is also the objective needs of social development. With the rapid development of science, technology and economy, people's mode of production, way of life and mode of thinking have taken place and are undergoing profound changes.

Therefore, students today should adapt to the needs of the division of labor tomorrow and try to develop their potentials and creativity. While imparting knowledge, we should teach them to master the principle of invention, techniques and methods, to consciously apply scientific thinking method, to engage in creative work of thinking industry ${ }^{[6]}$ in future jobs and to realize the fundamental purpose of education for future social development.

The cultivation of applied talents based on the three-in-one platform is also the fundamental demands of the enhancement of our country's competitiveness. Taking the laws of economic development and technological progress into account in various countries of the world, it is 
becoming increasingly clear that the competition in the political, military and economic aspects of the world's countries is always a manifestation of competition in science and technology, in fact, behind which it is the competition of education and that of the cultivation of applied talents.

\subsection{Inherent requirements of talent growth}

The cultivation of applied talents based on the three-in-one platform is the inherent requirements to reduce the loss of intellectual resources, to promote its rational flow, to achieve the best comprehensive effect and to realize the talent healthy growth and the people's all-round development.

The core of creativity of human intellectual resources is priceless compared with any material resource, as far as full exploitation and utilization of human creativity are concerned. There is no value in the potential intellectual resources that are not exploited and utilized in the human brain. If the material resources such as coal and oil are not to be mined and utilized by this generation, they can also be done by the next. But this is not the case for the intellectual resources of the human brain. If they are not fully exploited in the lifetime, and turn them into creative achievements and apply them in society, then they will disappear with the decay of the body when they leave the world, even though there are more creative potentials in the brains.

Not only that, but the disciplines become diverse and penetrating, and the inter-disciplines and peripheral disciplines are developing day by day with the development of modern science. It is necessary to exchange frequently talents, to change positions, to obtain experience and knowledge in all fields, to break the bonds of habitual thought and to avoid the formation of a closed system without material, energy and information exchange with the surrounding environment. However, to protect and promote the rational flow of intellectual resources smoothly, the boundaries of professions and disciplines must be crossed and the rigid situation in closed system broken.

On the whole, cultivating the applied talents based on the three-in-one platform of industry-university-research is the important guarantee to reduce the loss of intellectual resources, to promote its rational flow and to achieve the people's all-round development.

\section{Selection of realistic paths}

It is the selection of realistic paths to cultivate applied talents based on the three-in-one platform of industry-university-research for realizing the intersection of literal arts \& sciences, the integration of knowledge \& practice and the coordination of one specialty \& multi-capability.

\subsection{Intersection of literal arts and sciences}

Emphasizing the rationalization of knowledge structure and the intersection of literal arts \& sciences is one of the important paths to cultivate applied talents based on the three-in-one platform. In order to cultivate applied talents, many universities abroad emphasize the importance of general courses in formulating teaching plans and the mutual infiltration and intersecting of the liberal arts $\&$ sciences in the course setting ${ }^{[7]}$. In fact, the integration of curriculum contents abroad is regarded as one of the main means for cultivating applied talents based on the three-in-one platform.

Because of a variety of reasons, there are many shortcomings for China's higher education, such as the separation of liberal arts and sciences, the narrow majors and curricula. In order to change this situation, some domestic universities should refer to the successful experience abroad to focus on solving the problem of special \& versatile of knowledge and the separation of liberal arts \& sciences in higher education and should establish the benign knowledge structure. At present, some universities have begun to carry out the reform experiment of cultivating applied talents based on the three-in-one platform ${ }^{[8]}$. Students of liberal arts establish necessary science courses while students of science learn some liberal arts and both they establish a knowledge structure of the combination of the special and the versatile.

The tasks of the cultivation of applied talents based on the three-in-one platform also include double-subject system, elective subjects, lectures and exhibitions on science \& technology and humanities, participation in activities of scientific research, various comprehensive discipline 
competition, etc., which are all the effective approaches and internal requirements to broaden the horizon of knowledge, to increase the depth and breadth of knowledge and to improve the quality of sciences and humanities.

\subsection{Integration of knowledge and practice}

Strengthening the combination of theory $\&$ practice and the integration of knowledge $\&$ practice is also one of the important paths of cultivating applied talents based on the three-in-one platform. Currently, foreign universities attach great importance to the construction of three-in-one platform and to the cultivation of applied talents through the integration of knowledge $\&$ practice. American scholars emphasize to cultivate the practical ability of students to adapt to the social environment ${ }^{[9]}$. They point out that the goal of education is not only to impart knowledge to students, but also to cultivate students' ability of questioning, analyzing and solving problems, especially the operation ability.

Actually, the construction of three-in-one platform must be guided and guaranteed in the management system. It needs to strengthen practical teaching, raise the investment of practical education and teaching funds and increase publicity through promoting effective communication and coordination among universities, government, enterprises, industry departments and research institutions as well as all departments within the university in order to improve the quality and scale of cultivating applied talents and realize the integration of knowledge \& practice and the people's all-round development.

\subsection{Coordination of one specialty and multi-capability}

Promoting the comprehensive development among knowledge, ability \& quality and the coordination between one specialty \& multi-capability is one of the important paths to cultivate applied talents based on the three-in-one platform. Applied talents with one specialty and multi-capability refer to those who have ability in all aspects and are able to excel in a specific aspect. They are needed more and more for society in the era of fierce competition. They master a vocational skill with a higher level, at the same time also master some other professional skills related to their vocational skills. Generally speaking, one specialty corresponds to the core skill of a profession, which is reflected by one or more professional qualification certificates. The higher the level of vocational qualification certificate, the more in-depth the professional skills. Multi-capability corresponds to complex professional skills, innovative ability and basic quality of profession in related or near field, which is reflected by auxiliary professional qualification certificates or minor professional certificates. The more vocational qualification certificates, the more extensive and complex skills ${ }^{[10]}$. So applied talents with one specialty and multi-capability have higher technical quality, obvious superiority and competitive ability compared with the ordinary workers.

On the whole, effectively cultivating applied talents with the intersection of literal arts \& sciences, the integration of knowledge \& practice and the coordination of one specialty \& multi-capability is the inevitable paths and realistic selection for the reform and development of higher education, especially that of local colleges and universities in China through development, implementation and perfection of the three-in-one platform of industry-university-research.

\section{Summary}

The cultivation of applied talents should be established on the basis of the three-in-one platform of industry-university-research. It has become the mainstream trend of higher education development in the era of knowledge economy and it has received more and more widespread attention. The construction and perfection of the three-in-one platform is an important way to improve the comprehensive quality and competitive strength of applied talents and it is the important measures to mutually combine and jointly develop among universities, enterprises and research institutions. Only by summing up the historical experience and conforming to the objective development of the times, can its goals and tasks be realized in higher education. 
On the whole, it is of important theoretical and practical significance to attach importance to and implement the cultivation of applied talents based on the three-in-one platform of industry-university-research and to analyze and grasp the characteristics of the times, the historical inevitability and the selection of realistic paths for improving the quality of cultivating applied talents, deepening the reform of China's higher education, especially that of higher vocational education, and promoting the people's all-round development.

\section{Acknowledgement}

This research was financially supported by the Technology Talent Development Service Center, Ministry of Science and Technology (Grant NO. 11217210010001).

\section{References}

[1] B. Y. Hu. Retrospect and prospect of cooperative education of industry-university-research in our country, Education Information, vol. 23, pp. 152-155, 2010.

[2] J. G. Liu, S. N. Huang, Cultivating applied innovative talents: Problems, reasons and countermeasures, Theory and Practice of Contemporary Education, vol. 5, pp. 39-42, 2013.

[3] D. B. Qu, Y. S. Zhao, Problems and solutions of transformation and development of local undergraduate universities, China's Higher Education, vol. 12, pp. 24-28, 2014.

[4] L. J. Tian, Micro-reflection on the transformation and development of local colleges and universities --about dual system of occupation education in German, New Western (Theory Edition), vol. 6, pp. 124-125, 2014.

[5] M. Kazuyuki, University-industry coilabomtions in Japan: The role of new technology-based firms in transforming the national movation system, Research Policy, vol. 2, pp. 36-47, 2005.

[6] N. Jamaluddin, A. Ayob, S. A. Osman, M. Z. Omar, N. T. Kofli, S. Johar, Undergraduate industrial training experience: A win-win situation for students, industry and faculty, Procedia Social and Behavioral Sciences, vol. 6, pp. 648-653, 2013.

[7] A. Torres, G. Dutrenit, J. L. Sampedro, N. Becerra, What are the factors driving university industry linkages in latecomer firms: Evidence from Mexico, Science and Public Policy, vol. 38, pp. 31-42, 2011.

[8] A. Geuna, A. Musico, The governance of university knowledge transfer: A critical review of the literature, Springer Science and Business, vol. 9, pp. 93-115, 2009.

[9] Q. H. Shi, A. P. Wang, Basic characteristics of applied undergraduate education, Research on Education Development, vol. 21, pp. 34-37, 2008.

[10] M. H. Wang, X. J. Quan, Training and enlightenment of top innovative talents in American research universities, Education Research, vol. 12, pp. 149-155, 2014. 